\title{
Taking Responsibility for the Future: Ten Proposals for Shaping the Future of the Study of Culture into a Problem-Solving Paradigm
}

\section{On the Need for Rethinking, Reframing, and Reinventing the Study of Culture for the Twenty-first Century}

There is a curious lack of alignment between the challenges and problems that we face in the twenty-first century and the established ways in which academic disciplines and institutions have been organized since the nineteenth and twentieth centuries. At an early meeting of the International Advisory Board of the International Graduate Centre for the Study of Culture, which is the institutional site of knowledge production that has both shaped the observations and proposals in this essay, the renowned literary and cultural theorist Ursula Heise from UCLA once remarked that there is an unfortunate disparity between many of the concerns and issues with which the study of culture tries to come to terms and the disciplinary matrix and institutional frameworks within which we operate.

Note: For this essay I have drawn on and adapted some ideas and formulations that were first broached or developed in earlier articles (see especially Nünning 2010, 2012, 2014) and in passages that I contributed to introductions of co-edited volumes (see, e.g., Baumbach, Michaelis, and Nünning 2012; Nünning and Nünning 2010, 2018). Sections 7 and 10 are largely based on a reframed summary of Nünning (2014), from which several ideas and passages have been adapted and only slightly rephrased. Now that the extramural funding from the Excellence Initiative and the funding line called 'Graduate Schools' have unfortunately come to an end, I have also for the first time incorporated some of the ideas that were developed for the original proposal for the establishment of the "International Graduate Centre for the Study of Culture" submitted in 2006 and the renewal proposal of the GCSC from 2012 into an article.

On behalf of all the colleagues who have worked together at the GCSC, the three editors of this volume would like to express our and their tremendous gratitude for the generous financial support and extramural funding that the GCSC has received through the German Excellence Initiative from 2006 until 2019. I am also very grateful to my two co-editors, both for doing the lion's share of the editorial work and the fruitful collaboration over the last ten years or so. I would also like to thank my secretary Rose Lawson for her careful proof-reading, and Elizabeth Kovach for her copy-editing and for making valuable suggestions for improvement. 
Although Ursula Heise no doubt phrased her observations much more elegantly, the gist of it was that we are trying to solve twenty-first-century problems with theories, concepts, and methods developed in the twentieth century, while working within a disciplinary matrix and the constraints of institutions that largely emerged in the nineteenth century.

Quite a few scholars and commentators from diverse disciplinary and institutional backgrounds have recently made similar remarks. The well-known German social scientist Harald Welzer, for instance, observed that both the programmatic political blueprints and the economic and industrial policies that were developed in the twentieth century are ill-suited for finding adequate answers to the challenges of the twenty-first century, especially to the question of how the current level of civilization could be maintained with a radically reduced use of resources (see Welzer 2013, 220, 288). In a somewhat similar vein, Cathy Davidson also attributes current problems to the disparity between the challenges they pose and the outdated strategies we use in trying to cope with them: "If we're frustrated at the information overload, at not being able to manage it all, it may well be that we have begun to see the problems around us in a twenty-first century multifaceted way, but we're still acting with the individualistic, product-oriented, task-specific rules of the twentieth" (Davidson 2011, 7). In short, we seem to be facing a wide range of new challenges and twenty-first-century global (or postmodern) problems for which there are no ready-made, traditional, or modern solutions.

The disparity between the somewhat ill-suited concepts and methods as well as the equally outdated institutional and disciplinary arrangements and the most pressing challenges, concerns, and issues that the study of culture is faced with in the twenty-first century may be one of the reasons for a loss of faith in both the relevance of academic work and our ability to imagine or shape the future at large. This is exactly what Lawrence Grossberg, one of the most distinguished pioneers of cultural studies in the United States, suggested in his seminal book Cultural Studies in the Future Tense: "People seem to be losing their faith in their ability to shape the future. It is not that they do not care about the future, but that they no longer feel that their caring can shape the future. We take no responsibility for the future" (Grossberg 2010, 62, see 284). Although many activists and campaigns like 'Fridays for Future' serve to show that there are indeed people who still retain some faith in their ability to shape the future, I tend to agree with Grossberg that the latter have become the exceptions rather than the rule. While engaged activists from the younger generation have begun to hold politicians and established institutions accountable for the proliferation of ecological crises and natural disasters that threaten the future of our planet, attempts to respond to cultural issues that matter globally have largely been few and far between. 
Taking my cue from these observations, I would like to argue that we need to rethink, reframe, and even reinvent the study of culture in such a way as to ensure that there will be a better fit between current concerns of the twenty-first century (henceforth often abbreviated as C21 concerns or issues), on the one hand, and the conceptual, theoretical, and institutional frameworks with or within which we operate in the field of the study of culture, on the other hand. Moreover, as the title and subtitle of this essay (i.e., an essay in the original sense of the word, viz. an attempt) serve to emphasize, this essay argues that we should take responsibility for the future of both the study of culture and the world we live in by actively shaping the study of culture into a problem-solving paradigm, thus substantially reframing and even reinventing the field, the concepts and frameworks, and the projects and practices with which we are engaged. The emphasis in what follows will be on making some proposals for how the study of culture can be developed in such a way that it will not only have a future but also become an important interdisciplinary paradigm for coming to terms with key C21 issues.

Although the emphasis in both this volume and my essay is on the study of culture rather than the Anglo-American kind(s) of cultural studies, a contribution to a volume entitled Futures of the Study of Culture should offer clear answers to the two questions raised in the title of one of Grossberg's many important essays: "Does Cultural Studies Have Futures? Should It?" (2006). I am inclined to answer both questions in the affirmative, but I hasten to add that the study of culture will only have futures if we take full responsibility for them, i.e., if we are able and willing to develop relevant research agendas, reframe the concepts, theories, and methods we work with, and to state as clearly as possible why the study of culture matters in the twenty-first century more so than ever.

Since the title of this essay may sound grandiose and promise more than what I will be able to deliver, three brief provisos seem necessary. First, although it might go without saying, what follows is much more modest in scope than the comprehensive account that Grossberg delineates in his wide-ranging monograph Cultural Studies in the Future Tense, to which some of the suggestions made below are much indebted. Second, what follows does not claim to be about 'the' challenges, concerns, and issues that both contemporary societies and the study of culture are currently facing, but will instead only be able to cover a fraction of the wide array of aspects, dimensions, and issues that the topic of this volume addresses, focussing on some of the challenges and concerns that have not received as much attention as they arguably merit. Third, despite its emphasis on the future, this essay is neither an exercise in the emerging field of futures studies (aka futurology), nor an attempt to follow in the footsteps of Jonathan Swift. Apart from the intertextual reference in the subtitle to Swift's Juvenalian satirical essay, no irony or satire is intended. 


\section{Figuring out what is Going on, or: Challenging the Hegemonic Master Narratives and Fictions that Capitalist Cultures Live by, and Reframing Concerns, Conjunctures, and Contexts for the Study of Culture in the Twenty-first Century}

Although limitations of space preclude the possibility of comprehensively gauging what the most pressing challenges and concerns are at present or taking stock of the state of the art in the study of culture, taking responsibility for the future presupposes understanding "what's going on in the worlds in which we live" (Grossberg 2010,1) and the institutions in which we work. In his best-selling book 21 Lessons for the 21st Century, the historian Yuval Noah Harari (2018) provides a wide-ranging overview of some of the most important technological and political challenges that we are faced with in an age that has variously been dubbed the age of acceleration, the age of bewilderment, the age of climate change, the Anthropocene, and the digital age. One of the few things that most commentators still seem to agree on is that our contexts, technologies, forms of life and work, and the concerns that emerge in relation to them have changed so drastically and rapidly that most people no longer know what is going on: "it is hard to maintain a clear vision. Frequently, we don't even notice that a debate is going on, or what the key questions are" (Harari 2018, ix).

If we accept this general diagnosis, it follows that such a lack of clarity and consensus poses a real challenge for the study of culture. It results in not only a radically altered context in which there is not even agreement about what the agenda or the priorities should be but also new concerns, issues, and research questions. As Cathy Davidson observes, "When suddenly, abruptly, our context changes, we are forced then to pay attention to all the things we didn't see before" (Davidson 2011, 206). It is anything but clear, however, what we should really pay attention to as scholars of culture, because there is no consensus as to what the greatest challenges and concerns are in the twenty-first century (see Harari 2018, 1-2). It is hardly controversial, however, that not only the contexts but also the 'conjunctures' (see Grossberg 2006, 4) of today's societies have changed so much that it is anything but clear what the most important "Problem-Spaces of Cultural Studies" (Grossberg 2010, 43) actually are.

Since any attempt at defining these new conjunctures and problem-spaces in a single essay would be doomed to failure, my first two proposals are that we should challenge the hegemonic master narratives and fictions that capitalist cultures live by, and that we should then try to reframe the main concerns and 
conjunctures for the study of culture in the twenty-first century accordingly. We are currently witnessing a crisis of many of the hegemonic master narratives and stories that we (or Americans) live by (see McAdams 2013), and a concomitant emergence of alternative cultural, medial, and narrative ways of sense- and worldmaking. The study of culture (or narrative theory, for that matter) has hardly begun to address the loss of faith in the master narratives of growth and progress (see Hänggi 2015), the proliferation of crisis narratives, broken narratives, and new kinds of fictional storytelling like fragmented essay-novels. Being as much shaped by contemporary culture as shaping it in turn, this rise of new kinds of narratives in twenty-first-century storytelling presents a challenge to both the study of culture and the study of narratives, questioning some of their most cherished premises and concepts. In the Appendix of his book Living to Tell About It, James Phelan observes that "the living of our lives affects the way we tell our stories, where the telling of our stories affects the way we go on living, and where part of our living is given over to talking about our telling” (Phelan 2005, 205). This observation not only suggests that the way we live and the way we tell our stories mutually shape each other; it also implies that wide-ranging changes in the way we live will have a profound impact on how we tell stories and what kinds of narratives we choose.

Taking my cue from Phelan's emphasis on the mutual constitution of living and storytelling, I should like to venture the hypothesis that we are currently witnessing a crisis of many of the hegemonic master narratives and stories that capitalist, or western, cultures live by and a concomitant emergence of alternative ways of knowing, sense-, and worldmaking. For worse rather than for better, we seem to live in an age in which disrupted lives (see Becker 1997) and broken narratives have become the rule rather than the exception. I would even go so far as to maintain that the plethora of broken narratives across a broad range of domains, genres, and text-types may suggest that, in a digitally enhanced and fragmented age like ours, there may be a change of dominant between the hitherto prevailing forms of coherent and linear stories that have served as cultural templates and new kinds of broken narratives, fragmented novels, and other fragmentary and often multimodal hybrids that combine heterogeneous genres and text-types. In a stimulating online-essay, "Fragmentary: Writing in a Digital Age" (2012), Guy Patrick Cunningham suggests that "works that deal with fragmentation, that eschew not only a traditional narrative structure but the very idea of a work comprising a single, unified whole [...] take on a special kind of relevance."

Moreover, in an age of ongoing crises, it is probably no coincidence that broken narratives seem to have proliferated in various contexts beyond literature and the arts. Salient cases in point include the realms of the economy, banking and finance, as well as politics. As a result of the financial crises (see Lanchester 
2010) and soaring national debts, more and more banks, companies, and even states have been confronted with the fact that their cherished corporate or collective narratives no longer match recent developments. When financial dangers, debts, distress, and disorganization prevail, the collective narrative that tells the story of a firm or a nation may well be broken beyond repair. Moreover, we currently seem to be witnessing a crisis or even a breakdown of some of the master narratives that late capitalism has lived by, and it may well just be a question of time until the brokenness and obsolescence of master narratives such as those of economic growth, innovation, progress, and ever-growing prosperity will become impossible to ignore or overlook.

Being as much shaped by contemporary culture and altered forms of living as shaping them in turn, this rise of new kinds of narratives in twenty-first-century storytelling presents a challenge to both the study of culture and narrative theory, questioning some of their most cherished premises, concepts, and cultural templates. The phenomena that have been subsumed under the umbrella terms of 'broken narratives' and 'fragmented novels' challenge and even undermine key assumptions, i.e., that there is such a thing as a logic of narrative and that stories are endowed with orderly structures, coherence, and causality. Although it is definitely much too early to venture any hypotheses about whether such emergent narrative forms constitute a change of dominant in contemporary storytelling, their emergence and recent proliferation testifies to the fact that narratives not only shape cultures and world-models but are also very much shaped by them. Broken narratives and fragmented novels foreground wide-ranging changes in prevalent forms of life in the twenty-first century (see Jaeggi 2014; Basseler et al. 2015); they can be seen as articulations of significantly altered experiences in rapidly changing cultural contexts.

One of the most promising approaches to reframing concerns and contexts for the study of culture in the twenty-first century, therefore, seems to be to focus on the way in which cultures shape narratives and vice versa (see Nünning 2012). Renowned cultural psychologists go so far as to claim that "Storytelling becomes entwined with, even at times constitutive of, cultural life" (Bruner 2002, 31) and that, in our daily autobiographical practice of narrating our lives, "we draw some of our best material from master cultural narratives" (McAdams 2013, 84). Dan P. McAdams even goes so far as to maintain that we are still relatively ignorant about the key concepts and processes that shape cultures: "Beyond making vague references to things like 'my religious heritage' or 'the American Dream,' we tend to have remarkably little insight into the ways our lives are framed by cultural categories, values, and norms" (McAdams 2013, 271). His wide-ranging and brilliant account of the stories Americans live by could well serve as a model to be emulated in the study of other cultures: 
I would submit that life stories are more reflective of and shaped by culture than any other
aspect of personality. Stories are at the centre of culture. More than favored goals and values,
I believe, stories differentiate one culture from the next. I have argued throughout this book
that the stories people live by say as much about culture as they do about the people who
live and tell them. Our own life stories draw on the stories we learn as active participants
in culture - stories about childhood, adolescence, adulthood, and aging. Stories capture
and elaborate metaphors and images that are especially resonant in a given culture. Stories
distinguish between what culture glorifies as good characters and vilifies as bad characters.

(McAdams 2013, 284)

Exploring the ways in which cultures shape narratives just as much as narratives shape cultures could thus be an especially promising approach in order to reframe concerns and contexts for the study of culture in the twenty-first century. Since narratives can be conceptualized as "culturally mediated practices of (re)interpreting experience” (Meretoja 2018, 2), scholars engaged in both narrative studies and the study of culture need to be more "sensitive to the ways in which narratives as practices of sense-making are embedded in social, cultural, and historical worlds" (2). In order to come to grips with the ways in which cultures and narratives mutually constitute one another, we need to know much more about different communities' "stored narrative resources" (Bruner 1990, 67-68), what Bruner calls "culture's narrative resources" $(2002,93)$ and the cultural categories, values, and norms that frame and shape our lives.

\section{Exploring Cultural Ways of Worldmaking as a Paradigm for the Study of Culture in the Twenty-first Century}

If we accept the view delineated above that nobody can really tell what is happening right now due to an overload of information and a proliferation of competing accounts, narratives, and fictions (sensu Harari 2016, 2018), then challenging the hegemonic master narratives and reframing concerns and conjunctures for the study of culture in the twenty-first century needs to be supplemented with an exploration of how the worlds that we live in are fabricated or made. The news, for instance, purports merely to report what has happened but it really does much more than that. As Alain de Botton shrewdly observes in his book The News: "The news [...] fails to disclose that it does not merely report on the world, but is instead constantly at work crafting a new planet in our minds in line with its own often highly distinctive priorities" (de Botton 2014, 11). Media and especially the news 
thrive on catastrophes and crises, for instance, but what is often forgotten is that focussing on natural cataclysms and disaster and operating in a 24/7 crisis mode tell us more about the highly distinctive priorities of the media in question and their ways of worldmaking than about what is really going on in the world. As Susan Faludi has shown in her Pulitzer-Prize-winning and ground-breaking book Backlash (1991), the same holds true for the ways in which media campaigns often resort to dubious means such as skewed reporting with little or no evidence, wilfully fictitious news stories about alleged trends and the reinforcement of cultural myths and stereotypes that discredit feminist aspirations and obstruct women's equality.

In order to figure out what the main concerns and issues are in our present contexts and conjunctures, we need to know much more about how specific media and narratives establish and disseminate agendas, priorities, and worlds. Two related research questions concern the extent to which ways of worldmaking are not only imbued with cultural and ethical values but also implicated in power relations. The study of culture should thus pay much more attention to the ways in which media, metaphors, and narratives shape the cultural life of catastrophes and crises (see Meiner and Veel 2012; Nünning 2012), making highly biased mediaworlds that strongly distort people's prevailing views. The main point here is not just that the degree of what the late Hans Rosling (2018) has felicitously called "factfulness" is often dubious or questionable in the crisis-prone worldview that the media tend to project but that we tend to lose sight of both the ways in which "mediashock" (Grusin 2015) and the worlds of news and popular culture are made, as well as long-term developments that are arguably much more important.

Although there is broad consensus by now that narratives are of great importance for the ways in which we make sense of our experiences and the world, neither narrative theory nor the study of culture have been much concerned with the ways in which events, stories, and fictional or real worlds are made, or with the functions that various forms of cultural worldmaking can fulfil (see Nünning 2010). Narratives are at work in processes such as identity formation, the forging of communities and nations, the negotiation and dissemination of norms and values, and the fabrication of storied versions of 'the world.' As Jerome Bruner aptly observed, "narrative, including fictional narrative, gives shape to things in the real world and often bestows on them a title to reality" $(2002,8)$.

The constructivist notions that provide the epistemological underpinnings of Nelson Goodman's approach pertain to a wide range of different domains of worldmaking and to many cultural ways of worldmaking that we find in the media. They range all the way from Making Selves, to borrow the subtitle of a seminal book by Paul John Eakin (1999), to worldmaking in such domains as politics, law, and economics. The question of ways of worldmaking is particularly important in the case of narratives (both factual and fictional), as well as other 
literary genres and artistic media, in that stories are endowed with performative power, functioning as world-building media that project alternatives to the world-models that we generally regard as 'reality.' In addition, narratives often self-reflexively foreground and explore many of the epistemological and ontological questions involved in worldmaking. It thus does not come as a surprise that Jerome Bruner observed that "Nelson Goodman's constructivism arms one well to appreciate the complexities of self- and life-making” (Bruner 1991, 17), although it is equally clear that his analytical toolbox needs to be supplemented by other concepts. W. J. T. Mitchell was the first to explicitly address the question of "exactly what Goodman is excluding under the rubric of value" (Mitchell 1991, 23), exploring "the scope of Goodman's project, what lies inside and outside the domain of his inquiry” (Mitchell 1991, 24). According to Mitchell, "there are three basic subject areas that Goodman routinely excludes from his system: values, knowledge, and history" (24), but there are also other domains, forms, and functions of worldmaking that did not fall within Goodman's philosophical purview (see Nünning and Nünning 2010, 12-16).

While there is quite a lot of research and debate on the ways in which narratives serve as one of the most important means of self-making, neither narrative theory nor the study of culture have been much concerned with the performative power that storytelling exerts in many domains beyond narrative fiction and autobiography. Narratives, for instance, also contribute to what may be called 'community-making,' with genres and culturally available plots serving as the main interfaces between the making of selves and the making of communities. Narratives can be endowed with performative power, actively moulding, constructing, or even creating the cultural and ideological conflicts that they purport to merely reflect or represent. The stories disseminated by George W. Bush and his administration are a case in point. As an examination of former President Bush's speeches shows, his narratives of crisis not only offer paradigm examples of how storytelling can serve to make worlds and generate conflicts, but they also serve to illustrate that even wilfully fictitious stories can become 'weapons of mass destruction' (see Nünning and Nünning 2017). Several notable exceptions notwithstanding, narrative theory has yet to fully grasp such influential and ubiquitous narrative ways of worldmaking as "The News" (see de Botton 2014), the so-called 'social' networking services like Facebook, and the forms and functions of storytelling in organizations, politics, law, economics, and many other fields. The study of culture would certainly stand to gain if it paid more attention to the multiple functions that narratives perform (see the articles in Erll and Sommer 2019).

As I have argued elsewhere (Nünning and Nünning 2010), the complex processes involved in cultural and, particularly, narrative ways of worldmaking 
could well serve as a paradigm for the study of culture in the twenty-first century. Since "no one area of study can come to terms with the multidimensional complexity of narrative worldmaking" (Herman 2011, ix), Goodman's constructivist premises and his general approach tally well with the interdisciplinary nature of research in the study of culture. Although Goodman's analytical theory of worldmaking provides a highly flexible framework for comparative inquiry, it needs to be further developed and supplemented so that it becomes applicable to a broad range of cultural activities and processes, including journalism, literature, film, music, computer games, and other media. An alliance between theories of symbol systems (as delineated by Ernst Cassirer and Goodman), which pertain equally well to verbal, non-verbal, and performative ways of worldmaking (see Mitchell 1991, 25), and approaches developed by cultural studies could be an important force in the current reconceptualization of the study of culture: Such an alliance can open productive possibilities for the analysis of both the relationship between cultural ways of worldmaking and their changing contexts, and the epistemological, historical, and cultural implications of symbolic systems and signifying practices involved in worldmaking. In addition, such a move could throw new light on both the diachronic development of cultural ways of worldmaking and their changing functions. Another reason why the approach dubbed 'cultural ways of worldmaking' could serve as a model for the study of culture in the twenty-first century is thus its broad scope, which opens up a wide range of possible applications to diverse disciplines and fields of inquiry. The latter include the ways in which not just the news, media and politics but also the arts, humanities, and sciences and their academic ways of worldmaking constitute our everyday worlds.

The main reason why the issues involved in cultural ways of worldmaking could serve as a paradigm for the study of culture in the twenty-first century is that 'it shifts attention from 'culture' or 'cultural objects,' assumed to exist, ready to be examined, to the level of the concepts that we deploy to construct the objects of inquiry in the first place" (Nünning and Nünning 2010, 19). If we do not have access to the real world as such, and if the fictions, metaphors, and narratives we live by shape our mental worlds, then the most crucial issue is the question of how such worlds or world models are constructed and conceptualized in the first place. This question pertains to all the different actors, institutions, levels, and media involved in worldmaking, ranging all the way from first-order observations by participants in the cultural field to various second-order or even higherlevel observations by which old and new media make their worlds. The paradigm of cultural ways of worldmaking could thus be productively aligned with other approaches in cultural, media, and social theory, such as Bruno Latour's actor-network theory. 


\section{Re-Aligning the Study of Culture with Emerging Challenges, Concerns, and Problematics of the Twenty-first Century: New Conjunctures and Directions for the Study of Culture}

The suggestions made in the previous section were not meant to imply that the topic of cultural ways of worldmaking should be regarded as the paradigm of the study of culture, although it would arguably merit much greater attention than it has hitherto been granted. It was rather meant to serve as a paradigm example of how the research questions, concepts, and theoretical frameworks of the study of culture could be reframed to better re-align them with emerging challenges and current concerns. Although the notion of conjunctures (see Grossberg 2010, 40-53, 57-101) as one of the key concepts of cultural studies has not gained much traction in European versions of the study of culture, I completely agree with Grossberg's claims that exploring cultural phenomena and processes should be conceptualized as an inherently dynamic, flexible, and open-ended project rather than as a fixed and static discipline, and that it should also strive to construct the most relevant conjunctures. What Grossberg dubs "conjunctural analysis" or simply "conjuncturalism" "is a description of change, articulation, and contradiction; it describes a mobile multiplicity, the unity of which is always temporary and fractured" (Grossberg 2010, 41). Rather than examining a clearly delimited set of events or objects, the study of culture should thus respond to the ever-changing concerns, contexts, and problems that emerge in particular social formations and their ongoing debates about cultural issues. What Grossberg claims about cultural studies arguably pertains just as well to the study of culture: "Too many have forgotten that cultural studies is about conjunctures, and that to do it successfully, it has to reinvent itself - its theories, politics, and questions - in response to conjunctural conditions and demands” (65).

With a view to the future of the study of culture, it seems of paramount importance to take the inherently dynamic nature of the cultural phenomena and processes that constitute the objects of inquiry into account, defining research priorities in response to changing challenges and contexts and constructing conjunctures accordingly. Rather than think in terms of a limited number of fixed research areas, it seems much more productive to attempt to identify emerging concerns, issues, and topics that cut across disciplines and research fields. Such key recent issues include, for instance, the proliferation of crises in finance and the economy, the challenges involved in climate change, global warming, and demographic change, and the far-reaching consequences of such wide-ranging 
transformations as digitalization, globalization, and global migration. Cutting across the dividing lines between culture, technology, science, and society, these and other processes all constitute transdisciplinary challenges that should change the research priorities of the study of culture. The study of culture has yet to come to terms with such challenges as those posed by ethics in digital cultures (Spiekermann 2019; see also Erll et al. 2008) and the equally challenging questions surrounding the impact of digital media on how we think (see Hayles 2012; S. Greenfield 2014), or How to be Human in the Age of the Machine, to quote the subtitle of Hannah Fry's (2018) recent book about the benefits and dangers of an increasingly algorithm- and data-driven world.

I would now like to single out at least some of the most important issues and trends to which the study of culture could devote much more attention. These include, for instance, the unprecedented degree of commercialization of culture (both high-brow and popular), the radically altered media ecology that constitutes the cultural environment, and the unprecedented rise of digital information technologies and networks (see e.g. Morozov 2013; A. Greenfield 2017). Among the catalysts that have recently enhanced changes in the cultural field are the acceleration of digital innovations, the unprecedented growth of digital monopolies (see Taplin 2016), and the pervasive "colonization" of both everyday life and the domestic sphere by networked devices, products, and services provided by digital information technologies (see A. Greenfield 2017, 36, 286 and passim). Although the ongoing boom of the radical technologies that Adam Greenfield has analyzed and critiqued in his seminal monograph Radical Technologies (2017) is such a complex topic that it cannot be delineated here, it is important for anyone who is trying to understand the ways in which contemporary cultures are evolving to remember just how comprehensively the digital information technologies and networks that so many people nowadays take for granted have changed everyday experience, completely reshaping prevalent forms of life in the twenty-first century:

Networked digital information technology looms ever larger in all of our lives. It shapes our perceptions, conditions the choices available to us, and remakes our experiences of space and time. [...] It even inhibits our ability to think meaningfully about the future, tending to reframe any conversation about the reality we want to live in as a choice between varying shades of technical development.

(A. Greenfield 2017, 8)

The dominant forms of life and everyday experience in what Roberto Simanowski has christened Facebook-Gesellschaft (2016), i.e., Facebook society, and, even more so, in the more recent worlds dominated by Instagram, Snapchat, and Twitter, are largely shaped by digital information technologies (see A. Greenfield 2017) and their relentless rhythms of round-the-clock communication and consumption that 
the art historian Jonathan Crary (2014) has exposed and critiqued in his brilliant but somber exploration of nonstop neoliberal capitalism, 24/7. Crary's analyses tally well with the observations that the late sociologist Zygmunt Bauman made in his book Consuming Life (2007). Bauman uses the brilliantly polyvalent term 'consuming life' to describe the large degree to which contemporary forms of life are centered around the paradigm of consumption, transforming a society of producers into a society of consumers who end up consuming their lives. Contributing to a transformation of the consumer into a commodity, digital and social media (see Lanier 2018) arguably play a central role in the process of reconfiguring cultures and forms of life, affecting the very basics of life. As Crary (2014) shows, we are beginning to sacrifice sleep to a marketplace that operates $24 / 7$, resulting in a collective fatigue that increasingly characterizes our dominant forms of life. The rapid acceleration of all walks of life in late capitalism has generated a 24/7 lifestyle that provides hardly any space to breathe. We are supposed to consume and communicate electronically round the clock, being monitored with digital surveillance techniques that would have made George Orwell's Big Brother blush with envy. According to Crary, this process will eventually lead to the end of sleep (see Crary 2014) and, in his brilliant analysis of the contemporary cultural imaginary, he illustrates perceptively how the widely used expression 'digital age' can be regarded as a questionable act of historiographic construction. It does not constitute a neutral representation of contemporary culture at all but rather blocks out a large number of aspects and experiences that are just as constitutive for the culture(s) of today but incommensurable with the culture's fixation on technical progress and growth: "This pseudo-historical formulation of the present age as a digital age, supposedly homologous with a 'bronze age' or 'steam age,' perpetuates the illusion of a unifying and durable coherence to the many incommensurable constituents of contemporary experience” (Crary 2014, 36).

Therefore, the disruptions brought about by the rise of digital information technologies and the concomitant changes in dominant forms of life, as farreaching as they have been, are by no means the only relevant contexts against which recent developments and trajectories of contemporary cultures should be gauged. On the contrary, it would be equally (in)accurate to claim that we are living in an age of crises (e.g., the debt crisis, other financial crises, or the refugee crisis), an age of terrorism and the so-called 'war on terror' (see Hodges 2011), an age of surveillance, an age of climate change, and the Anthropocene (see Harari 2016, ch. 2), or an age of world-wide migration and refugee crises.

Moreover, any attempt to construct the most relevant conjunctures of today's cultures has to acknowledge that these diverse contextual developments are not isolated but rather interlinked in various ways. The banking and debt crises, for instance, were not just cataclysmic events in the systems of finance and the 
economy but rather had devastating consequences for society as a whole, changing cultures, the mental climate, and the dominant hierarchy of values in significant ways. As the prolific journalist and novelist John Lanchester has shown in his highly readable account of the financial crisis entitled Whoops! Why Everyone Owes Everyone and No One Can Pay, the "hegemony of economic, or quasieconomic, thinking” (Lanchester 2010, 187) has been so damaging for Britain and the Western world at large because the "economic metaphor came to be applied to every aspect of modern life, especially the areas where it simply didn't belong” (187-188). He goes on to argue that instead of having discussions about values and principles, the emphasis has almost exclusively been on costs:

In Britain in the last twenty to thirty years that has all been the wrong way round. There was a kind of reverse takeover, in which City values came to dominate the whole of British life. There needs to be a general acceptance that the model has failed. [...] the model which spread from the City to government and from there through the whole culture, in which the idea of value has gradually faded to be replaced by the idea of price.

(Lanchester 2010, 188)

These examples may suffice to illustrate what should be taken into consideration in attempts at constructing conjunctures that would re-align the study of culture with key C21 concerns. Even the apparently arcane world of finance or the bank and debt crises of the economy, just like ubiquitous digital information technologies, have had, and continue to have, far-reaching consequences for culture and society at large, shaping not just the dominant hierarchy of values and ideologies, but also the design of everyday life and prevailing notions about living together in a multicultural world. Although the major difficulties in constructing a research agenda and defining priorities derive from the fact that there are so many different cultural, economic, political, social, and technological contexts that could, and should, be taken into consideration, it is of great importance that we begin to construct new conjunctures by describing and explaining the concomitant changes in the cultural spheres and relating them to one or several of these contexts. Many cultural practitioners have responded to the various crises that have occurred in the aftermath of 9/11 and the so-called 'war on terror,' the banking and debt crises since 2008, as well as many further cultural and social issues that have shaped the new millennium. These include, for instance, the 'costs' of modernization, acceleration and globalization, which manifest themselves in, e.g., performance indicators, evaluations, and 'burnout' in the brave new worlds of 'new public management' (see Bartmann 2012) and disruptions in the job market in many branches and industries. Other questions about contemporary cultures revolve around the fact that we are living in multicultural societies that are increasingly marked by worldwide migration, competing forms of life and values, and conflicts of integration and identity that result from these developments. 
Moreover, processes of slow change and gradual transformation such as climate change and global warming, "mind change" (S. Greenfield 2014) and the disruptions caused by digital technologies (see A. Greenfield 2017) in a wide range of cultural forms of production, from journalism and music (see Taplin 2017) to the literary field, certainly deserve much more sustained attention within the study of culture. The same holds true for the wide-ranging and devastating effects that economic competition and the doctrine of growth has had, and continues to have, on the ecology and environment: "Even as economic disparity is increasing, competition is urged with fundamentalist fervor as the single solution to all problems. Ecological health continues to elude us - and perhaps indeed depends upon the reconstruction of patterns of thought" (Mary Catherine Bateson 2000, xii; in: Bateson 1972/2000).

In order to ensure that the study of culture will have a sustainable future, it is not enough to merely address and respond to such changing concerns, contexts, and their respective problematics. Rather, we must attempt to develop such emergent problematics into fully-fledged research fields. The French literary historian Yves Citton has done just that with regard to what he has felicitously called the recent shift "From Attention Economy to Attention Ecology" (Citton 2018, 1), serving as a model well worth emulating. Although he concedes that "hyperattention fed by digital acceleration is not inevitably going to undermine the foundations of our capacity for deep concentration," he hastens to add that "something major is being reconfigured, in which the distribution of attention already plays a major role. [...] Attention is the crucial resource of our epoch" (Citton 2018, 10). Citton not only outlines a highly fruitful approach to the new research field of what the title of his book names "the ecology of attention," but he also develops a coherent conceptual and theoretical framework for exploring the wide-ranging changes that we have witnessed in the spheres of "Attention Regimes" (27), "Attentional Capitalism" (44) and “The Digitalization of Attention" (63), to quote some of the key concepts used as chapter titles in Part I one of his book, in which he also includes some words of advice and warning that we would ignore at our own peril:

Knowing how to choose our alienations and our enthralments, knowing how to establish vacuoles of silence capable of protecting us from the incessant communication that overloads us with crushing information, knowing how to inhabit the switches between hyper-focusing and hypo-focusing - this is what aesthetic experiences (musical, cinematic, theatrical, literary or video-gaming) can help us do with our attention, since attention is always just as much something that we $d o$ (by ourselves) as something that we pay (to another).

(Citton 2018, 19)

At the risk of repetition, I would like to reiterate what I said at the beginning of this section: The discussion of these new contexts and concerns is not meant to 
suggest that these developments should be regarded as the new objects or the most important topics of the study of culture. They are rather meant to serve as paradigm examples that could illustrate how the research profile and priorities of the study of culture could be better aligned with major concerns, challenges, and pressing problems of the twenty-first century.

\section{Recalibrating Key Concepts for the Study of Culture in the Twenty-first Century: Stock-taking and Enriching our Conceptual and Theoretical Frameworks}

The next proposal follows directly from the previous one in that the suggestion to re-align the study of culture with emerging challenges, concerns, and problematics of the twenty-first century necessitates taking stock of the concepts we have been working with, recalibrating them and enriching the extant conceptual and theoretical frameworks by developing additional concepts in order to account for new contexts, conjunctures, and problematics. The notion of 'travelling concepts' as developed by the Dutch cultural theorist Mieke Bal (2002) has had a remarkable impact on recent approaches in cultural analysis and the study of culture at large, opening up new avenues for interdisciplinary exchange, while also introducing an important self-reflexive dimension to the field. Bal's fruitful project proceeds from the assumption that concepts are indispensable for the study of culture because they are "the tools of intersubjectivity" and "key to intersubjective understanding" in that "they facilitate discussion on the basis of a common language" (Bal 2002, 22). Bal also observes that concepts "offer miniature theories" (22), also referred to as "shorthand theories" (23), a claim based on the influential concepts that metonymically represent, or evoke, more complex theories such as, for example, cultural memory (see Erll and Nünning 2008).

Following in Bal's footsteps, several recent volumes have not only traced the dynamic travelling of concepts between academic disciplines and across research cultures (see, e.g., Baumbach et al. 2012), but they have also provided an overview of main concepts and cutting-edge research fields in the study of culture (see Neumann and Nünning 2012). The chapters in these volumes also show that the "meaning, reach, and operational value" (Bal 2002, 24) of concepts differ between disciplines, academic cultures, and historical periods. Concepts in the study of culture are usually not univocal, fixed, or firmly established. Rather they are dynamic and flexible, undergoing semantic changes as they travel back and forth 
"between disciplines, between individual scholars, between historical periods, and between geographically dispersed academic communities" (Bal 2002, 24), which are often shaped by different national research cultures and traditions.

Taking stock of the travelling concepts we have been working with in the study of culture and their respective journeys, however, is arguably not enough if we want to realign our conceptual and theoretical frameworks with current concerns and emerging fields. This involves much more than simply making an inventory of key concepts. Rather, it entails a sober exploration of the unspoken assumptions, implications, and ideological baggage that concepts in the field of cultural analysis typically entail. To a much greater extent than in the sciences, we do not deal with clearly defined concepts but rather conceptual metaphors and metaphorical concepts. Travelling across various axes, key concepts in the study of culture tend to gravitate into the force fields of metaphors and narratives (see Baumbach et al. 2012). Imbued with, and shaped by, their respective historical and national traditions, concepts typically come with an array of semantic implications, often including ideological freight, unconscious biases, and normative implications.

In order to decide whether established concepts are still adequate in addressing current concerns and research questions, an especially promising approach may well be to carefully examine their semantic implications and their respective affordances and constraints. While the notion of constraints refers to both the limitations of a concept, pattern or shape and its unacknowledged ideological implications or presuppositions, the term 'affordance' foregrounds the range of possibilities or potentialities a concept entails or opens. In her convincing and powerful proposal for a new formalism that serves to connect aesthetic, literary, and symbolic forms to historical, political, and social contexts, Caroline Levine introduces the concepts of affordances and constraints as follows:

To capture the complex operations of social and literary forms, I borrow the concept of affordance from design theory. Affordance is a term used to describe the potential uses of actions latent in materials and designs. [...] Let's now use affordances to think about form. The advantage of this perspective is that it allows us to grasp both the specificity and the generality of forms - both the particular constraints and possibilities that different forms afford, and the fact that those patterns and arrangements carry their affordances with them as they move across time and space.

(Levine 2015, 6)

This perspective can be applied to the key concepts we work with in the study of culture. We can interrogate the respective affordances and constraints of different concepts. In his analysis of the concept of globalization, Grossberg has, for instance, convincingly demonstrated that discourses of globalization tend to have very particular affordances and constraints in that the presuppositions 
of this concept inevitably "set up a particular structural logic - an inescapable binary logic of the global vs. the local, which is applied across every possible dimension" (Grossberg 2010, 60). The same arguably holds true for many of the key concepts of postcolonial theory and postcolonial discourse analysis, to mention just two additional cases in point. As Dipesh Chakrabarty has shown in his influential book Provincializing Europe, every case of transferring a cultural, economic or political concept, model or theory from one context to another is "a problem of translation" (Chakrabarty 2000/2008, 17) - a translation of existing worlds, their "conceptual horizons" and their thought-categories into the context, concepts and horizons of another life-world (see Chakrabarty 2000/2008, 71). He also draws attention to the important but often unacknowledged facts that any seemingly "abstract and universal idea" can "look utterly different in different historical contexts," no country is "a model to another country," "historical differences actually make a difference," and "no human society is a tabula rasa" (Chakrabarty 2000/2008, xii). What Chakrabarty observes about the "universal concepts of political modernity" also holds true for every approach and concept in the study of culture that is transferred from one academic context or discipline to another: such travelling concepts "encounter pre-existing concepts, categories, institutions, and practices through which they get translated and configured differently" (xii). This should be kept in mind when trying to gauge the challenges and possibilities offered by the notion of travelling concepts in general and when assessing the usefulness and limitations of particular key concepts for coming to terms with $\mathrm{C} 21$ concerns.

The need to recalibrate and update key concepts in the study of culture is not only a result of constantly changing contexts. It also arises from the fact that concepts are 'operative terms' (see Welsch 1997); they are never merely descriptive but "also programmatic and normative" (Bal 2002, 28). Concepts construct and change the very objects to which they are applied (see Welsch 1997, 20), "entailing new emphases and a new ordering of the phenomena within the complex objects constituting the cultural field" (Bal 2002, 33). It is thus vital for the development of the study of culture in an interdisciplinary and transnational framework that we maintain awareness of these epistemological implications and continue to develop new and more nuanced concepts for addressing the constantly changing cultural fields of the twenty-first century.

Relatively recent additions to our conceptual repertoire have been the concepts of affect, media events and “mediashock” (Grusin 2015), 'ritual dynamics' as developed by the science of ritual (see Michaels 2010-2011), transculturality, resilience, and the notion of cultural resources. The latter is the key concept around which the projects in the collaborative research centre "RessourceCultures" at the University of Tübingen revolve, which focuses on the socio-cultural 
dynamics of using resources. In order to gain a better understanding of how cultures and societies manage to cope with the kinds of crises that Europe has been faced with for more than a decade, the study of culture should, for instance, explore the cultural resources of resilience.

Recalibrating key concepts for the study of culture involves not only developing new categories and enriching extant theoretical frameworks but also reframing and retheorizing concepts that have been around for a while but were never fully explicated (see Berning et al. 2014). An obvious case in point is Raymond Williams' rich notion of "structure of feeling," which has only recently (re)gained the attention it deserves in a volume that explores the importance of affectivity in various research areas of the study of culture (see Sharma and Tygstrup 2015). Similarly, the essays in a volume edited by Doris Bachmann-Medick and Jens Kugele (2018) revisit established analytical tools in the study of migration, showing that we need to reframe migration if we approach it from a conceptual perspective and confront established terminologies with recent cultural and discursive frameworks as well as historical and political realities that are all too often referred to as 'the refugee crisis,' a biased and loaded term that already frames the events in an ideologically and politically charged manner. Changing concepts in this field involves, for instance, taking practices of visibility and visualization (including invisibility and making unwelcome people invisible) into account, reframing mobility and the structure of the collective unconscious, taking a fresh look at border regimes and borders as conflict zones, and reconceptualizing migration as translation (for detailed explorations, see the essays in Bachmann-Medick and Kugele 2018).

In order to avoid possible or even obvious misunderstandings, I would like to emphasize, however, that the plea to re-align the study of culture with emerging challenges, concerns, and C21 problematics is by no means meant to suggest that the concepts and issues surrounding, e.g., identity politics have lost any of their former relevance. On the contrary, both the categories of race, class, and gender, and ongoing debates about structural racism, blatant or latent misogyny, and other ingrained forms of inequality continue to be as relevant as they were in the twentieth century. One could even go so far as to say that there is a dire need for more research on the subtle forms that racism, misogyny, and anti-feminism have taken in the twenty-first century and that there has been a backlash against both anti-racism and feminism. As Reni Eddo-Lodge (2018, 99-100) has persuasively shown, in Britain there has been "a backlash against conversations about white privilege” (Eddo-Lodge 2018, 99) and "a backlash against any and all anti-racist organising” (100). Similarly, in the preface to the 15th anniversary edition of Backlash, originally published in 1991, Faludi shows that we have witnessed several developments in the twenty-first century that are arguably "worse than backlash" 
(2006, xiii) in that "the very fundaments of feminism have been recast in commercial terms" (xiv): "The feminist ethic of economic independence has become the golden apple of buying power", the "feminist ethic of self-determination has turned into the golden apple of "self-improvement"' (xv), and "the feminist ethic of public agency has shape-shifted into the golden apple of publicity” (xv).

The recent boom of so-called 'social media' and the concomitant emergence of a "Facebook society" (Simanowski 2015), a Twitter-filter bubble, Instagram, Snapchat, and YouTube cultures revolving almost entirely around people's physical appearance not only amply substantiate these prophetic statements, but they also underscore the need to rethink feminism and identity politics in new conceptual, contextual, and theoretical frameworks. Moreover, as recent research in intersectionality has demonstrated, we should redirect our attention from a focus on just one of the categories of difference that define identities to the various ways in which age, class, ethnicity, gender, sexuality, nationality, and others are entangled and interlinked with radically altered media environments, networked digital information technologies, and an equally changed economy and ecology of attention (see Citton 2018). In addition, such recent media phenomena as the worlds generated by Instagram, Twitter, and YouTube, or "WeTube" (see Greif 2016, 200-210), and the peculiar "Reality of Reality Television" (177-199) have yet to receive the degree of attention that they arguably deserve as new cultural ways of worldmaking.

\section{Responding to the Epistemological Crisis and Proliferation of Fictions: Reclaiming Authority, Credibility, and Truth for the Study of Culture}

The next proposal is a direct follow-up to the previous one in that the key concepts of objectivity and truth upon which research in the humanities and the sciences are based, just like the notion of scientific knowledge, have recently been challenged. Although the challenging of scientific truth is not a recent phenomenon but something that has quite a long and sorry history, it has gained new urgency in an age in which the distinctions between fact and fiction have become increasingly blurred and in which oxymora like 'alternative facts' or dubious notions like 'fake news' and 'post-truth' are gaining currency. As the historians of science Naomi Oreskes and Erik M. Conway have demonstrated in their seminal book Merchants of Doubt (2012), not only journalists and politicians but also groups of scientists have been involved in disseminating doubt about "the Truth on Issues from Tobacco Smoke to Global Warming," as the subtitle of their 
book succinctly states. In recent years, debates about what is really going on, about whether the consensus that science has established about global threats such as climate change and global warming can be trusted, has become even more ferocious, often revealing a blatant lack of respect for research and the very notion of scientific knowledge. If counter-narratives without a shred of scientific evidence can be constructed and disseminated by popular and so-called social media, gaining wide acceptance and even credibility, then genuine research will sooner or later be in dire straits.

One of the most pernicious effects of these alarming tendencies, which pertain to every academic discipline, is the proliferation of "ideological fictions" (Harari 2016, 151). Such fictions not only have the power to sow seeds of doubt (see Oreskes and Conway 2012, 66) and call scientific consensus into question, but they can even undermine the notions of objective reality and scientific truth: "As human fictions are translated into genetic and electronic codes, the intersubjective reality will swallow up the objective reality and biology will merge with history" (Harari 2016, 151). Although Harari has quipped that "humans have always lived in the age of post-truth" and that homo sapiens could even be defined as "a post-truth species, whose power depends on creating and believing fictions” (2018, 233), the proliferation of 'alternative facts,' fake news, and ideological fictions constitutes a real challenge to academic work, scholarly research, and the notion of scientific knowledge, threatening the very existence of universities as institutions in their own right.

On the other hand, the proliferation of various kinds of fictions is also a great challenge and opportunity for the study of culture in that it opens up an important new field of research. As experts in both literary fiction and cultural ways of self-, community-, and worldmaking (see section 2 above), scholars engaged in the study of culture should apply their conceptual expertise, methodological knowhow, and analytical research techniques to understand how such ideological fictions are constructed and disseminated as well as the functions they fulfill. Simply dismissing ideological fictions as bullshit (sensu Harry Frankfurt 2005), fake news, or lies is arguably a serious sin of omission in that it would fail to acknowledge both the fact that "some fake news lasts forever" (Harari 2018, 231) and that such fictions often have pernicious effects. We might therefore be much better advised to heed Harari's clarion call and put the examination of fictions onto our research agenda, because fictions serve as important ways of meaning- and sense-making:

In the twenty-first century fiction might therefore become the most potent force on earth, surpassing even wayward asteroids and natural selection. Hence, if we want to understand our future, cracking genomes and crunching numbers is hardly enough. We must also decipher the fictions that give meaning to the world.

(Harari 2016, 151) 
I would even go so far as to claim that the alarming proliferation of bullshit, fake-news and fictions not only tends to undermine the authority, credibility, and reliability of scholarly research and of scientific knowledge, but that these tendencies have also become so widespread that they arguably constitute nothing less than an epistemological crisis. A brief look at how the renowned philosopher Alasdair MacIntyre explains the connection between culture and narrative schemata will hopefully clarify this claim. According to MacIntyre, cultures can be understood as communities that share foundational schemata: "Consider what it is to share a culture. It is to share schemata which are at one and the same time constitutive of and normative for intelligible action by myself and are also means for my interpretations of the actions of others" (MacIntyre 1977, 453). When global processes become more complicated, and when it becomes more difficult to know the truth about the world because of competing accounts, then such a co-existence of incompatible schemata and irreconcilable world models can lead to an epistemological crisis: "it is also the case that the individual may come to recognise the possibility of systematically different possibilities of interpretation, of the existence of alternative and rival schemata which yield mutually incompatible accounts of what is going on around him. Just this is the form of epistemological crisis encountered by ordinary agents and it is striking that there is not a single account of it anywhere in the literature of academic philosophy" (MacIntyre 1977, 454). Although the publication of MacIntyre's pioneering essay on the subject dates back more than forty years, no publication that I have come across has managed to offer a better account of how such an epistemological crisis can be resolved:

When an epistemological crisis is resolved, it is by the construction of a new narrative which enables the agent to understand both how he or she could intelligibly have held his or her original beliefs and how he or she could have been so drastically misled by them. The narrative in terms of which he or she at first understood and ordered experiences is itself made into the subject of an enlarged narrative. The agent has come to understand how the criteria of truth and understanding must be reformulated. He has to become epistemologically self-conscious.

(MacIntyre 1977, 455)

Three of the most challenging and important tasks for the study of culture, at least from my point of view, would thus be to devote much more attention to the proliferation of ideological fictions and to an exploration of the resulting epistemological crisis, to reclaim authority, credibility, and truth for the study of culture as well as scientific knowledge in general, and to attempt to tell better narratives and stories than those that currently occupy the headlines and shape the agendas of universities (see section 10 below). Even though the majority of people may well continue to prefer fictions to the truth, it is up to us to remind the public that 
"the scientific community has been our most reliable source of knowledge for centuries” (Harari 2018, 244).

Movements such as the series of international demonstrations and rallies held under the banner of 'March for Science' serve to show that an increasing number of scholars and scientists from around the world are beginning to understand how urgent it has become to stand up for academic freedom, the indispensable value of research, and scientific knowledge. It is high time that the study of culture not only joined forces with movements such as 'March for Science' and 'Fridays for Future' but also started to employ its expertise and research methodologies in an exploration of the proliferation of fictions, the concomitant epistemological crisis, and their far-reaching detrimental effects.

\section{Fostering Internationalization and Pluralism: Transnationalizing Approaches for the Study of Culture in the Twenty-first Century}

Although the next proposal might amount to forcing an open door in an age of globalization and worldwide mobility, I would still like to suggest that we should continue to foster more sustained international collaboration and transnational approaches to the study of culture. The study of culture is, after all, itself very much a cultural practice characterized by local traditions and national specificity. As I have discussed elsewhere (see Nünning 2014), approaches to the study of culture as practised in different countries still display considerable differences due to factors such as language, intellectual style, respective cultural contexts, historical developments of disciplines and approaches, and institutional differences between national research cultures and traditions. German Kulturwissenschaften and British cultural studies, for instance, are two national traditions with significant differences. The development of genuinely transnational, or even trans-European, approaches to the study of culture is still a desideratum for future research.

Some recent contributions to research have, however, begun to fill the void. These include approaches that either cut across national traditions or have successfully travelled from one research culture to others. A number of influential 'cultural turns' (Bachmann-Medick 2016) in the humanities or 'cultural sciences' (Kulturwissenschaften) as well as the notions of 'travelling concepts' (Bal 2002) and 'translation' offer promising ways of overcoming boundaries between research cultures and national traditions. During the last two decades, there have been 
sustained attempts at Internationalizing Cultural Studies, to borrow the title of an anthology edited by Ackbar Abbas and John Nguyet Erni (2005), as the study of culture has been one of the most rapidly developing fields in European and American universities and has also emerged in Asian and Australian scholarship (see Bachmann-Medick 2014, 1-22).

We deliberately chose the more neutral and open term 'study of culture' over the Anglo-American term cultural studies or the German notion of Kulturwissenschaften for this volume and the entire book series. It signals that our project of developing transnational approaches to the study of culture does not refer to any narrow understanding of the object of study, a particular theoretical approach, national research tradition or school of thought, as is the case with, for example, 'cultural studies,' 'cultural analysis' (Bal 2002, 6-8), 'cultural materialism,' and 'cultural criticism' (Belsey 2003). The goal is, rather, to enhance the dialogue among these and other approaches, disciplines, and cultures of research to foster self-reflexive, interdisciplinary, international, and potentially even transnational approaches.

The development of transnational approaches to the study of culture does not privilege any one approach but should rather display a commitment to theoretical and methodological pluralism. An approach resulting from an anthropological, semiotic, and constructivist understanding of culture that characterizes many recent approaches is a prerequisite for the rich exchange that takes place in transdisciplinary and international research undertakings. Approaches that have cut across disciplinary and national research traditions include, e.g., cultural semiotics, cultural anthropology, historical anthropology, literary anthropology, the new cultural history, cultural ecology, and area studies (for an overview, see Nünning and Nünning 2008). Although the traditions, research foci, and methodologies of these different ways of studying culture differ substantially, these approaches all embrace inter- or transdisciplinary collaboration and an international, or even global, orientation.

In an article entitled "Cultural Studies and the Transnational," the Canadian cultural theorist Imre Szeman has demonstrated that the notion of the transnational (referred to as a "concept-metaphor"; Szeman 2007, 200) "forces us to consider seriously that the very object of cultural studies - culture - has been radically changed in ways that require the activity of the field to shift from what has remained its basic orientation: the study of cultural objects and practices of everyday life in relation to power" (202). Szeman also carefully delineates three levels on which the transnational functions within cultural studies: cultural studies as a transnational discipline; the field's examination of transnational contexts, issues, and sites; and the political and epistemological challenges involved in the transfer of British and American cultural studies to other contexts. 
While it may well be "apparent that cultural studies as a professional practice is now truly transnational" (203), what is much less clear is whether there have been any sustained attempts at inter- or transnationalizing research traditions and practices themselves.

In addition, the notion of transnationalization challenges established Eurocentric and American concepts used to denote modern cultures and collectives such as the nation-state and the polity. It draws attention to the interconnections between polity, nation, and culture in their various manifestations within language, media, memory, and identity. Itself a major mode of the diffusion, transfer, and problematization of key concepts, a transnational perspective epitomizes the emergent character of concepts and the necessity for greater self-reflexivity. It also illuminates transnational cultural phenomena (e.g., Hollywood and Bollywood movies, popular music and MTV, a new understanding of world literature) that have proliferated in the age of globalization and the historical and heuristic reconfigurations of culture, society, and the polity that these phenomena have demanded.

Szeman states that "an interrogation of the potential cultural parochialisms and conceptual blind spots of cultural studies constitutes [...] one of the most important and compelling 'theoretical' projects in the field today" $(2007,206)$. Transnational approaches to the study of culture could serve as important contributors to such a project. The same holds true for my plea to recalibrate key concepts and explore the processes of appropriation, reframing (see Berning et al. 2014), and translation that are involved in the travelling of concepts. To the extent that the meaning of such concepts must be constantly renegotiated, a sustained enquiry into the dynamics of such travelling, including the " "translational' processes" (Chakrabarty 2000/2008, 19) and politics involved and the genealogies of the concepts in question (see section 5 above), is a prerequisite for the development of transnational approaches to C21 challenges in the study of culture.

\section{Reinventing the Practices and Institutional Frameworks of Knowledge Production: The Study of Culture as a Collaborative, Evidence- Based, and Interdisciplinary Practice}

Another daunting but important task for anyone interested in securing viable futures for the study of culture is to get involved in the attempt to shape and remake the institutional sites and practices of knowledge production. Since the 
study of culture is an interdisciplinary project, we need institutional frameworks that foster and support collaborative work and interdisciplinary conversation across different cultures of research. It is certainly not a coincidence that cultural studies only began to rise to prominence after the Centre for Contemporary Cultural Studies had been established at the University of Birmingham in 1964 and that, even decades later, international luminaries such as Lawrence Grossberg continue to sing their praises for the stimulating research environment that the CCCS generated (see Grossberg 2010).

Moreover, research cultures are themselves subject to historical change, and both cultural studies and German Kulturwissenschaften have undergone far-reaching developments and important innovations in recent years. In comparison to the programmatic mission encapsulated in the name of the Birmingham Centre for Contemporary Cultural Studies, which suggests that cultural studies "is a field devoted entirely to the immediate present" (Felski 2003, 501), for instance, from today's point of view the "rationale for isolating the study of popular, contemporary culture from high culture and the culture of the past now seems purely historical” (Belsey 2003, 91). In an article entitled "Beyond Literature and Cultural Studies," Catherine Belsey made a programmatic proposal that calls for "a new discipline [...], beyond literature and Cultural Studies, that would explicitly treat all culture as its province, and would take full advantage of the attention French theory pays to the signifier" (Belsey 2003, 99).

Taking my cue from Cathy Davidson's call for what she called “a Project Workplace Makeover” (2011, 167), I would even go so far as to make a similar plea for 'a Project Institution Makeover' for the study of culture. Davidson is certainly right when she observes that it is high time that we began to rethink and reinvent our institutions for research and teaching: "What we haven't done yet is rethink how we need to be organizing our institutions - our schools, our offices - to maximize the opportunities of our digital era" (Davidson 2011, 12). There has also been relatively little debate about how we should organize our universities, faculties, and departments to make the best of both the scholarly expertise that we find in different departments and faculties that pertain to the study of culture. We also need to overcome the disparity between disciplinary specialization dating back to the nineteenth and twentieth centuries and the concerns and challenges we are facing in the new millennium, almost all of which demand interdisciplinary collaboration. The standardized ways in which our institutions have traditionally been organized "may have worked for the twentieth century, but do they always and necessarily make sense for the twenty-first" (Davidson 2011, 220221)? Moreover, the limits imposed by disciplinary boundaries and bureaucracy are often "hostile to creative thinking" (Graeber 2016, 146), posing unnecessary 
administrative obstacles rather than fostering collaboration across disciplines and impending conceptual breakthroughs. Such an institutional makeover would also have to address, and critique, such detrimental developments as the ongoing bureaucratization and corporatization of many universities, the increasing reliance on extramural funding, research assessment exercises, and grant agencies. This has involved an "extraordinary squandering of human creativity" (Graeber 2019, 188), not least due to the concomitant proliferation of administrative tasks, paperwork, and increase in what the anthropologist David Graeber, who is fortunately never one to mince words, has designated "bullshit jobs" (2019).

Since the predominant division of labor between faculties, departments, and disciplines is anything but conducive to fostering interdisciplinary projects, we arguably need institutions and research centres that are specifically designed for the study of culture. Re-aligning the study of culture with emerging concerns presupposes that we continue to challenge disciplinary boundaries and develop the study of culture as an interdisciplinary practice. None of the daunting developments that threaten us most in the twenty-first century seem to do us the favor of falling into the scope of just one academic discipline. No matter whether we are dealing with phenomena or processes such as climate change, "mind change" (Greenfield 2014) and other effects of digitalization, or ways of worldmaking, for that matter, coming to terms with any of these or other current challenges involves interdisciplinary collaboration.

As the exemplary discussion of some of the emerging concerns in section 4 above has already indicated, an institutional makeover of the humanities and social sciences is arguably not enough. Coming to terms with such transdisciplinary challenges necessitates forging new collaborative interfaces between the study of culture and disciplines such as economics, law, medicine, psychology, and theology, to name but a few in which cultural aspects are particularly prominent. Initiating dialogues across disciplinary borders between the humanities, social sciences, and life sciences is an important first step, but in order to explore new cross-disciplinary research fields like those briefly discussed above, we need to establish new institutions for important emerging fields like environmental humanities, medical humanities, and the cultures of the economy and law.

Recent international developments have considerably broadened the aims and scope of what falls under the purview of cultural studies or the study of culture, both historically and as far as the synchronic range of forms of art and culture are concerned. Cases in point include the Amsterdam School for Cultural Analysis (ASCA), the European Summer School in Cultural Studies (ESSCS), the Lisbon Summer School for the Study of Culture, and the International Graduate Centre for the Study of Culture (GCSC). These international research networks 
and institutions have managed to foster new models of collaboration and bring the modes of reasoning and research methodologies from a broad range of disciplines (ranging from history, sociology, and political science to literary and theatre studies) into the study of culture. They have also firmly established and institutionalized the study of culture as a collaborative, evidence-based, and interdisciplinary practice, thus making important contributions to a better understanding of current issues that no discipline can get to grips with on its own: "Collaboration by difference is an antidote to attention blindness. It signifies that the complex and interconnected problems of our time cannot be solved by anyone alone" (Davidson 2011, 100). Such a method is extremely well suited for the kinds of inter- and transdisciplinary projects needed in the study of culture for the twenty-first century, as Davidson's comments illustrate: “Collaboration by difference respects and rewards different forms and levels of expertise, perspective, culture, age, ability, and insight, treating difference not as a deficit but as a point of distinction" (100). Seen in this light, collaboration by difference might be one of the keys for updating dominant methods in such a way as to re-align them for the cross-disciplinary challenges we face in the new millennium:

If the twentieth century was all about training experts and then not paying attention to certain things because the experts would take care of the matter for you, the twentyfirst is about crowdsourcing that expertise, contributing to one another's fund of knowledge, and learning how to work together towards solutions to problems.

(Davidson 2011, 258)

Such international research networks and institutions as those mentioned above could well serve as models to be emulated if we want to ensure that the study of culture will be able to make important contributions towards solving problems and thus really have a sustainable future for the simple reason that people will begin to understand that such a problem-solving paradigm is indispensable for society. These models have not only demonstrated how the transfer of approaches, concepts, and methodologies between diverse disciplines and academic cultures can be organized and advanced, but they have also managed to create sustained structures for research organization and research training in the field of the study of culture. Since such structures provide the necessary institutional basis for initiating research in innovative, interdisciplinary research areas, investing creative energy, resources, and time in the development and building of such institutions and initiating new projects might be one of the most promising ways of ensuring sustainable futures for the study of culture. 


\section{Moving beyond Critique, or: A Vision for the Study of Culture as a Problem-Solving Practice for the Twenty-first Century}

The second but last proposal can be very brief, because it refers to an important plea that Rita Felski developed in great detail concerning literary studies (see Felski 2015). My point here is simply that her observations about the preponderance of critique over other approaches and ways of knowledge production pertain just as much to the study of culture, and arguably even more so to cultural studies, as to literary criticism and literary studies. Anglo-American forms of cultural studies have traditionally been conceived of as politically engaged projects that put a heavy emphasis on critique. British cultural studies were developed as a response to concrete social and political challenges of the British class system and as a politically motivated project aimed at producing changes in society and strategies of resistance. While culture and politics have always been inextricably intertwined in this research tradition, the German tradition of Kulturwissenschaften, which can be traced back to the late nineteenth and early twentieth centuries, has quite a different genealogy, lineage, and non-political agenda, is largely an academic enterprise that explores cultural phenomena as objects of academic research without an eye towards engendering political change.

Notwithstanding such differences, however, Felski's observations about what she calls "the malaise of critique" (Felski 2015, 119) and her plea for the need to move beyond the dominant model of critique applies equally well to cultural studies: "Yet the malaise of critique could also free us up to reassess our current ways of reading and reasoning: to experiment with modes of argument less tightly bound to exposure, demystification, and the lure of the negative" (Felski 2015, 119-120). Similarly, the range of theoretical and methodological approaches she suggests as fruitful alternatives to critique could also open up new horizons for research in the study of culture, in which, e.g., phenomenology and other non-political forms of reading (e.g. "actor-network theory, post-historicist criticism, affective hermeneutics”; Felski 2015, 182) have enjoyed greater prominence than in American or British cultural studies.

I would like to go even further, however, in that I conceive of the study of culture not as a dominantly critical project geared at debunking, demystifying or exposing forms of discrimination or ideologies, but as a paradigm actively engaged in problem-solving. Putting the emphasis on problem-solving would not only involve challenging ingrained assumptions and practices, but it would also arguably be very productive in initiating conversations across disciplinary borders between the humanities, social sciences, and life sciences (see section 
8 above). It is in such cross- or trans-disciplinary research fields like environmental humanities, medical humanities, and the cultures of the economy and law that scholars involved in the study of culture could really make worthwhile contributions to solving, rather than merely critiquing, real problems - even though critique has and always will also have an important role to play. The questions of whether the study of culture should be about critique or problem-solving is not an either/or but rather a both/and issue, but we would arguably be well advised if we moved beyond critique and managed to develop better stories, both for the study of culture and the future(s) of the world at large.

\section{Developing Positive Visions for the Future(s) of the Study of Culture: Imagining Alternative Positive Futures and Telling Better Future Narratives}

Taken together, the previous proposals could be summed up in the overall suggestion to develop positive visions for the future(s) of the study of culture by telling better narratives of the futures of both the world we live in and the interdisciplinary field in which we work. We could thus turn recent insights into the reality-constituting function of narratives to our own advantage and bear in mind that "narratives both expand and diminish our sense of the possible" (Meretoja $2018,2)$. Instead of accepting the stories disseminated either in the realms of politics and the media or the largely apocalyptic and dystopian visions of the future in popular culture, we should bear in mind Grossberg's wise and witty reminder that “Bad Stories Make Bad Politics!” (Grossberg 2010, 64). My final and overarching proposal is thus that we should scrutinize hegemonic master narratives that no longer make sense of the world as it is and try to invent much better stories.

To propose narrative constructions for the future of the study of culture, we could follow the constructivist advice of Brian McHale:

it is important to distinguish among better and less good stories - "better" not in the sense of objectively truer (a criterion discredited by the constructivist approach), but in terms of such criteria as rightness of fit, validity of inference, internal consistency, appropriateness of scope, and above all productivity.

(McHale 1992, 9)

If we look at the dominant master narratives of modernity and capitalism in terms of McHale's criteria, we find that they no longer display rightness of fit, 
have ceased to be appropriate in today's world and are no longer sustainable. Much more work needs to be done to gauge the complex challenges and concerns with which we are faced, and to conceive and develop fully-fledged transnational approaches and concepts for the study of culture that meet such criteria.

It therefore seems apt to conclude by once again stressing the need for developing and debating the trans/national dimension of the study of culture. Anyone interested in transnational approaches to the study of culture that are re-aligned with C21 problematics can profit considerably from comparing different national approaches and considering the ways in which such influential traditions are discursively constructed and institutionally implemented. What is needed for the development of such approaches is an enhanced degree of self-reflection about different national traditions in 'doing' the study of culture, the promotion of greater "transnational literacy” (Bal 2002, 291), an openness to interdisciplinarity, and a questioning of one's own academic routines. Several promising new departures have served to internationalize and even transnationalize approaches to the study of culture, such as the volumes and anthologies Internationalizing Cultural Studies: An Anthology (Abbas and Erni 2005), The Worlding Project: Doing Cultural Studies in the Era of Globalization (Connery and Wilson 2007), New Cultural Studies: Adventures in Theory (Hall and Birchall 2007), and The Trans/ National Study of Culture: A Translational Perspective (Bachmann-Medick 2014), all of which delineate promising trajectories for developing a transnational study of culture.

We have also witnessed sustained attempts to develop new forms of 'global' cultural studies. Although an Institute for Global Cultural Studies (IGCS) was founded as early as 1991 at Binghampton University, with other universities offering programmes on global cultural studies following suit (e.g., Point Park University and most recently Université Jean Moulin Lyon 3), there have also been critical voices expressing scepticism against the very notion of 'a global cultural studies.' Jon Stratton and Ien Ang's warning that the "'internationalization' of cultural studies cannot mean the formation of a global, universally generalisable set of theories and objects of study" $(1996,363)$ may still serve as a timely reminder that the field of the study of culture may not lend itself particularly well to universalizing or transnationalizing gestures, and even less to attempts to develop universal theories of any cultural object, phenomenon, or process. In a particularly stimulating and thought-provoking review essay, Imre Szeman assesses the notion of “Global Cultural Studies" (Szeman 2011), carefully gauging both the risks and promises of such an ambitious project, and the political and epistemological problems that it entails. We face both "national-cultural situations, events, and circumstances" and a more or less "shared global critico-theoretical discourse" (Szeman 2011, 148), though the latter indeed tends to be "heavily weighted towards 
ideas emerging from Anglo-American and European traditions” (148). I not only agree but would add that we should redress the balance by provincializing (sensu Chakrabarty 2000) hitherto dominant approaches and following up on the ten proposals made here.

While cultural studies may well have gone international or even transnational in some instances, there is still a great need to further develop innovative and truly transnational approaches to the study of culture that are equipped to come to terms with such global challenges and transnational questions of the twenty-first century as highlighted by Harari:

What will happen to the job market once artificial intelligence outperforms humans in most cognitive tasks? What will be the political impact of a massive new class of economically useless people? What will happen to relationships, families and pension funds when nanotechnology and regenerative medicine turn eighty into the new fifty? What will happen to human society when biotechnology enables us to have designer babies, and to open unprecedented gaps between rich and poor?

(Harari 2016, 269)

Although it may be a tall order to try to change disciplinary traditions, institutional contexts, and theoretical frameworks dating back to the twentieth century (if not before) in such a way as to align them with the concerns and challenges of the twenty-first century, there is definitely a real need for the kind of conceptual and institutional project makeover outlined above (see section 8).

Moreover, we should neither give up hope nor forget that everything could be different, to translate the title of Harald Welzer's (2019) recent book. Even ingrained disciplinary traditions and institutional arrangements can be changed if there are enough dedicated and enthusiastic people willing to collaborate in order to challenge and change them: “Don't give up hope. Departmental cultures can change. And there can be subcultures of support within departments creating pockets of resistance to the effects of the corporate university" (Berg and Seeber 2016, 84). The study of culture will only have a future if the scholars working in the field are prepared to take full responsibility for it and take Max Tegmark's wise words that "we need more mindful optimists" to heart (Tegmark 2017, 334). It is certainly high time that we "re-orientate ourselves from an exclusive preoccupation with retrospectively making meaning(s) to the creative activity of making future(s), prospectively" (Bode and Dietrich 2013, 107; bold-print emphasis in the original).

The ten proposals made above are an attempt to sketch some of the tasks that are involved in such an endeavor, outlining what the most promising trajectories may be. I am perfectly aware, however, that these proposals are relatively general and that they need to be fleshed out in a much more detailed fashion. Therefore I would like to leave the last words to the late psychologist Christopher Peterson, 
whose ambivalent self-assessment of his own vision for the future of psychology also expresses my own sense of striving to strike the right balance between aiming high while being perfectly aware of the limitations of what we can achieve:

As a research psychologist, my goal is to do studies that are important and interesting, that answer questions about weighty matters, and that suggest ways to enhance the psychological good life. This is a vision with which I am quite happy, although it is of course vague. When I start to flesh out the vision, the process too often gets mired down by my worries about the means.

(Peterson 2013, 321-322)

\section{References}

Abbas, Ackbar, and John Nguyet Erni, eds. Internationalizing Cultural Studies: An Anthology. Malden, MA/Oxford/Carlton: Blackwell, 2005.

Allatson, Paul. Key Terms in Latino/a Cultural and Literary Studies. Malden, MA/Oxford/Carlton: Blackwell, 2007.

Bachmann-Medick, Doris, ed. The Trans/National Study of Culture: A Translational Perspective. Berlin/Boston: De Gruyter, 2014.

Bachmann-Medick, Doris. Cultural Turns: New Orientations in the Study of Culture. Berlin/ Boston: De Gruyter, 2016.

Bachmann-Medick, Doris, and Jens Kugele, eds. Migration: Changing Concepts, Critical Approaches. Berlin/Boston: De Gruyter, 2018.

Bal, Mieke. Travelling Concepts in the Humanities: A Rough Guide. Toronto: University of Toronto Press, 2002.

Bal, Mieke. "Working with Concepts." Travelling Concepts in English Studies. EJES: European Journal of English Studies 13.1 (2009): 13-24.

Bartmann, Christoph. Die Rückkehr der Diener. Das neue Bürgertum und sein Personal. Munich: Hanser, 2016.

Basseler, Michael, Daniel Hartley, and Ansgar Nünning, eds. Emergent Forms of Life in Anglophone Literature: Conceptual Frameworks and Critical Analyses. Trier: WVT, 2015.

Bateson, Gregory. Steps to an Ecology of Mind. With a new Foreword by Mary Catherine Bateson. Chicago/London: University of Chicago Press, 2000 [1972].

Bauman, Zygmunt. Leben als Konsum. Hamburg: Hamburger Edition, 2009 (orig.: Consuming Life. London: Polity, 2007).

Baumbach, Sibylle, Beatrice Michaelis, and Ansgar Nünning, eds. Travelling Concepts, Metaphors, and Narratives: Literary and Cultural Studies in an Age of Interdisciplinary Research. Trier: WVT, 2012.

Becker, Gaylene. Disrupted Lives: How People Create Meaning in a Chaotic World. Berkeley/Los Angeles/London: University of California Press, 1997.

Belsey, Catherine. "Beyond Literature and Cultural Studies: The Case for Cultural Criticism." Belgian Journal of English Language and Literatures New Series 1. Thematic Issue (2003): 91-100.

Berg, Maggie, and Barbara K. Seeber. The Slow Professor: Challenging the Culture of Speed in the Academy. Toronto/Buffalo/London: University of Toronto Press, 2016. 
Berning, Nora, Ansgar Nünning, and Christine Schwanecke, eds. Reframing Concepts in Literary and Cultural Studies: Theorizing and Analyzing Conceptual Transfers. Trier: WVT, 2014.

Bode, Christoph, and Rainer Dietrich. Future Narratives: Theory, Poetics, and Media-Historical Moment. Berlin/Boston: De Gruyter, 2013.

Bruner, Jerome. Acts of Meaning. Cambridge, MA/London: Harvard University Press, 1990.

Bruner, Jerome. "Self-Making and World-Making." Journal of Aesthetic Education 25.1 (1991): 67-78.

Bruner, Jerome. Making Stories: Law, Literature, Life. Cambridge, MA/London: Harvard University Press, 2002.

Chakrabarty, Dipesh. Provincializing Europe: Postcolonial Thought and Historical Difference. Reissue, with a new preface by the author. Princeton/Oxford: Princeton University Press, 2008 [2000].

Citton, Yves. The Ecology of Attention. Cambridge/Malden, MA: Polity, 2018.

Connery, Christopher Leigh, and Rob Wilson, eds. The Worlding Project: Doing Cultural Studies in the Era of Globalization. Santa Cruz: New Pacific, 2007.

Crary, Jonathan. 24/7: Late Capitalism and the Ends of Sleep. London/New York: Verso, 2014.

Cunningham, Guy Patrick. "Fragmentary: Writing in a Digital Age.” 2016. http://www.themillions. com/2012/01/fragmentary-writing-in-a-digital-age.html [accessed: 22 November 2019].

Davidson, Cathy C. Now You See It: How Technology and Brain Science will Transform Schools and Business for the 21st Century. London: Penguin, 2011.

De Botton, Alain. The News: A User's Manual. London: Pantheon, 2014.

Eakin, Paul John. How Our Lives Become Stories: Making Selves. Ithaca: Cornell University Press, 1999.

Eddo-Lodge, Reni. Why l'm no Longer Talking to White People about Race. London et al.: Bloomsbury, 2018.

Erll, Astrid, and Ansgar Nünning, eds. Cultural Memory Studies: An International and Interdisciplinary Handbook. Berlin/New York: De Gruyter, 2008.

Erll, Astrid, Herbert Grabes, and Ansgar Nünning, eds. Ethics in Culture: The Dissemination of Values Through Literature and Other Media. Berlin/New York: De Gruyter, 2008.

Erll, Astrid, and Ansgar Nünning, eds. A Companion to Cultural Memory Studies. Berlin/ New York: De Gruyter, 2010.

Erll, Astrid, and Roy Sommer, eds. Narrative in Culture. Berlin/Boston: De Gruyter, 2019.

Faludi, Susan. Backlash: The Undeclared War Against American Women. New York: Three Rivers Press, 2006 [1991].

Felski, Rita. "Modernist Studies and Cultural Studies: Reflections on Method.“ Modernism/ Modernity 10.3 (2003): 501-517.

Felski, Rita. The Limits of Critique. Chicago/London: University of Chicago Press, 2015.

Fluck, Winfried, Donald Pease, and John Carlos Rowe, eds. Re-framing the Transnational Turn in American Studies. Hanover: Dartmouth College Press, 2011.

Franck, Georg. Ökonomie der Aufmerksamkeit. Ein Entwurf. Munich: Hanser, 1998.

Frankfurt, Harry. On Bullshit. Princeton/Oxford: Princeton University Press, 2005.

Fry, Hannah. Hello World: How to be Human in the Age of the Machine. London: Transworld/ Black Swann, 2018.

Goodman, Nelson. Ways of Worldmaking. 1978. Indianapolis: Hackett, 1992.

Grabes, Herbert, Ansgar Nünning, and Sibylle Baumbach, eds. Metaphors Shaping Culture and Theory. REAL: Yearbook of Research in English and American Literature 25. Tübingen: Narr, 2009. 
Graeber, David. The Utopia of Rules: On Technology, Stupidity, and the Secret Joys of Bureaucracy. Brooklyn/London: Melville House, 2016.

Graeber, David. Bullshit Jobs: A Theory. London/New York: Penguin, 2019.

Greenfield, Adam. Radical Technologies: The Design of Everyday Life. London/New York: Verso, 2017.

Greenfield, Susan. Mind Change: How Digital Technologies are Leaving their Mark on our Brains. London: Penguin, 2014.

Greif, Mark. Against Everything: On Dishonest Times. London/New York: Verso, 2016.

Grossberg, Lawrence. "Does Cultural Studies Have Futures? Should It? (Or What's the Matter with New York?)." Cultural Studies 20.1 (2006): 1-32.

Grossberg, Lawrence. Cultural Studies in the Future Tense. Durham, NC/London: Duke University Press, 2010.

Grusin, Richard. "Mediashock." Structures of Feeling: Affectivity and the Study of Culture. Eds. Devika Sharma and Frederik Tygstrup. Berlin/Boston: De Gruyter, 2015. 29-39.

Hall, Gary, and Clare Birchall, eds. New Cultural Studies: Adventures in Theory. Athens: The University of Georgia Press, 2007.

Hänggi, Marcel. Fortschrittsgeschichten. Für einen guten Umgang mit Technik, Frankfurt a.M.: Fischer, 2015.

Harari, Yuval Noah. Homo Deus: A Brief History of Tomorrow. London: Harvill Secker, 2016.

Harari, Yuval Noah. 21 Lessons for the 21st Century. London: Jonathan Cape, 2018.

Hayles, N. Katherine. How We Think: Digital Media and Contemporary Technogenesis. Chicago/ London: University of Chicago Press, 2012.

Herman, David. “Editor's Column: Principles and Practices of Narrative Worldmaking.” Storyworlds 3 (2011): vii-x.

Hodges, Adam. The "War on Terror" Narrative: Discourse and Intertextuality in the Construction and Contestation of Sociopolitical Reality. Oxford: Oxford University Press, 2011.

Jaeggi, Rahel. Kritik von Lebensformen. Berlin: Suhrkamp, 2014.

Kovach, Elizabeth. Novel Ontologies after 9/11: The Politics of Being in Contemporary Theory and U.S. - American Narrative Fiction. Trier: WVT, 2016.

Lanchester, John. Whoops! Why Everyone Owes Everyone and No One Can Pay. London: Penguin, 2010.

Lanier, Jaron. Ten Arguments for Deleting Your Social Media Accounts Right Now. London: Bodley Heade, 2018.

Levine, Caroline. Forms: Whole, Rhythm, Hierarchy, Network. Princeton/Oxford: Princeton University Press, 2015.

Lynch, Michael Patrick. The Internet of Us: Knowing More and Understanding Less in the Age of Big Data. New York/London: Liveright Publishing Corporation, 2016.

MacIntyre, Alasdair. "Epistemological Crises, Dramatic Narrative, and the Philosophy of Science." The Monist 60.4 (1977): 453-471 (reprinted in: Maclntyre, Alasdair. The Tasks of Philosophy: Selected Essays. Vol.1. Cambridge: Cambridge University Press, 2006. 3-23.)

MacIntyre, Alasdair. After Virtue: A Study in Moral Theory. London: Bloomsbury, 2013 [1981].

McAdams, Dan P. The Redemptive Self: Stories Americans Live By. Oxford: Oxford University Press, 2013.

McHale, Brian. Constructing Postmodernism. London: Routledge, 1992.

Meiner, Carsten, and Kristin Veel, eds. The Cultural Life of Catastrophes and Crises: Facts, Forms, Fantasies. Berlin/New York: De Gruyter, 2012. 
Meretoja, Hanna. The Ethics of Storytelling: Narrative Hermeneutics, History, and the Possible. Oxford: Oxford University Press, 2018.

Mersmann, Birgit, and Hans G. Kippenberg, eds. The Humanities between Global Integration and Cultural Diversity. Berlin/Boston: De Gruyter, 2016.

Michaels, Axel, ed. Ritual Dynamics and the Science of Ritual. Vol. 1-5. Wiesbaden: Harrasowitz, 2010-2011.

Mitchell, W.J.T. “Realism, Irrealism, and Ideology: A Critique of Nelson Goodman.” The Journal of Aesthetic Education 25.1 (1991): 23-35.

Morozov, Evgeny. To Save Everything, Click Here: Technology, Solutionism and the Urge to Fix Problems That Don't Exist. London/New York: Allen Lane, 2013.

Neumann, Birgit, and Ansgar Nünning, eds. Travelling Concepts for the Study of Culture. Berlin/ New York: De Gruyter, 2012.

Nünning, Ansgar. "Making Events - Making Stories - Making Worlds: Ways of Worldmaking from a Narratological Point of View." Cultural Ways of Worldmaking: Media and Narratives. Eds. Vera Nünning, Ansgar Nünning, and Birgit Neumann. Berlin/New York: De Gruyter, 2010. 191-214.

Nünning, Ansgar. "Narrativist Approaches and Narratological Concepts for the Study of Culture." Travelling Concepts for the Study of Culture. Eds. Birgit Neumann and Ansgar Nünning. Berlin/New York: De Gruyter, 2012. 145-183.

Nünning, Ansgar, ed. Metzler Lexikon Literatur- und Kulturtheorie. Ansätze - Personen Grundbegriffe. 5th ed. Stuttgart/Weimar: Metzler, 2013 [1998].

Nünning, Ansgar. "Towards Transnational Approaches to the Study of Culture: From Cultural Studies and Kulturwissenschaften to a Transnational Study of Culture." The Trans/National Study of Culture: A Translational Perspective. Ed. Doris Bachmann-Medick. Berlin/Boston: De Gruyter, 2014. 23-49.

Nünning, Ansgar, and Vera Nünning. "Ways of Worldmaking as a Model for the Study of Culture: Theoretical Frameworks, Epistemological Underpinnings, New Horizons." Cultural Ways of Worldmaking: Media and Narratives. Eds. Vera Nünning, Ansgar Nünning, and Birgit Neumann. Berlin/New York: De Gruyter, 2010. 1-25.

Nünning, Ansgar, and Vera Nünning. “Conceptualizing ‘Broken Narratives’ from a Narratological Perspective: Domains, Concepts, Features, Functions and Suggestions for Research.” Narrative im Bruch. Theoretische Positionen und Anwendungen. Eds. Anna Babka, Marlen Bidwell-Steiner, and Wolfgang Müller-Funk. Göttingen: Vienna University Press, 2016. 37-86.

Nünning, Ansgar, and Kai Sicks, eds. Turning Points: Concepts and Narratives of Change in Literature and Other Media. Berlin/New York: De Gruyter, 2012.

Nünning, Vera, and Ansgar Nünning. "Stories as 'Weapons of Mass Destruction', or: George W. Bush's Narratives of Crisis as Paradigm Examples of Ways of World- and Conflict-Making (and Conflict-Solving?)." Narrative(s) in Conflict. Eds. Wolfgang Müller-Funk and Clemens Ruthner. Berlin/Boston: De Gruyter, 2017. 189-229.

Nünning, Vera, and Ansgar Nünning. "Cultural Concerns, Literary Developments, Critical Debates: Contextualizing the Dynamics of Generic Change and Trajectories of the British Novel in the Twenty-first Century." The British Novel in the Twenty-First Century: Cultural Concerns - Literary Developments - Model Interpretations. Eds. Vera Nünning and Ansgar Nünning. Trier: WVT, 2018. 21-52.

Nünning, Vera, Ansgar Nünning, and Birgit Neumann, eds. Cultural Ways of Worldmaking: Media and Narratives. Berlin/New York: De Gruyter, 2010. 
Oreskes, Naomi, and Erik M. Conway. Merchants of Doubt: How a Handful of Scientists Obscured the Truth on Issues from Tobacco Smoke to Global Warming. London/New York: Bloomsbury, 2012.

Peterson, Christopher. Pursuing the Good Life: 100 Reflections on Positive Psychology. New York/Oxford: Oxford University Press, 2013.

Phelan, James. Living to Tell About It: A Rhetoric and Ethics of Character Narration. Ithaca/ London: Cornell University Press, 2005.

Rosling, Hans. Factfulness: Ten Reasons Why We're Wrong About the World - and Why Things Are Better than You Think. London: Hoddert and Stoughton, 2018.

Sharma, Devika, and Frederik Tygstrup, eds. Structures of Feeling: Affectivity and the Study of Culture. Berlin/Boston: De Gruyter, 2015.

Simanowski, Roberto. Facebook-Gesellschaft. Berlin: Matthes \& Seitz, 2016.

Spiekermann, Sarah. Digitale Ethik. Ein Wertesystem für das 21. Jahrhundert. Munich: Droemer, 2019.

Stratton, Jon, and len Ang. "On the Impossibility of a Global Cultural Studies: 'British' Cultural Studies in an 'International' Frame." Stuart Hall: Critical Dialogues in Cultural Studies. Eds. David Morley and Kuan-Hsing Chen. New York: Routledge, 1996. 361-391.

Szeman, Imre. "Cultural Studies and the Transnational." New Cultural Studies: Adventures in Theory. Eds. Gary Hall and Clare Birchall. Athens: The University of Georgia Press, 2007. 200-218.

Szeman, Imre. “Global Cultural Studies?” The Minnesota Review 76 (2011): 147-161.

Taplin, Jonathan. Move Fast and Break Things: How Facebook, Google and Amazon Have Cornered Culture and what it Means for All of Us. London: Macmillan, 2017.

Tegmark, Max. Life 3.0: Being Human in the Age of Artificial Intelligence. London/New York: Penguin, 2017.

Turkle, Sherry. Reclaiming Conversation: The Power of Talk in the Digital Age. New York: Penguin, 2015.

Twenge, Jean M. iGen: Why Today's Super-Connected Kids are Growing Up Less Rebellious, More Tolerant, Less Happy - and Completely Unprepared for Adulthood. New York/London: Atria, 2017.

Welsch, Wolfgang. “Transkulturalität.” Universitas 52.607 (1997): 16-24.

Welzer, Harald. Selbst Denken. Eine Anleitung zum Widerstand. Frankfurt a.M.: Fischer, 2013.

Welzer, Harald. Die smarte Diktatur. Ein Angriff auf unsere Freiheit. Frankfurt a.M.: Fischer, 2016.

Welzer, Harald. Alles könnte anders sein. Eine Gesellschaftsutopie für freie Menschen. Frankfurt a.M.: Fischer, 2019.

Woolf, Maryanne. Tales of Literacy for the 21st Century. Oxford: Oxford University Press, 2016.

Woolf, Maryanne. Reader, Come Home: The Reading Brain in a Digital World. New York: HarperCollins, 2018. 